\title{
YOUNG CHILDREN'S FREEDOM OF CHOICE IN CHILD-CENTRED EDUCATIONAL PRACTICE
}

\author{
Aija Ozola \\ Rezekne Academy of Technologies
}

\begin{abstract}
The importance of young children's freedom of choice has been discussed since Froebel's and Montessori's contribution to the pedagogical ideas related to early childhood education. However, the theoretical framework of the term and its contents in modern early childhood education does not offer detailed description and would rather be characterized as incomplete and fragmented. The current study is an attempt to partly fill the gap between educational theory and practice basing on early childhood teachers' empirical experience and beliefs on children's freedom of choice.

The aim of the study is to identify early childhood teachers' beliefs on children's freedom of choice in child-centred educational practice. Focus group discussions were conducted with early childhood teachers implementing early childhood curriculum in municipal early childhood education institutions located in Riga, the capital city of Latvia. Data were analysed using the method of qualitative content analysis. The findings revealed very positive attitude of teachers towards children's freedom of choice and existence of teachers' personal meaning of the term and its contents. The benefits and possible risks of implementing children's freedom of choice were identified as well as factors enabling and hindering its implementation.
\end{abstract}

Keywords: child-centred education, early childhood education, freedom of choice, teachers' beliefs.

\section{Introduction}

The importance of young children's freedom of choice has been discussed since Froebel's and Montessori's contribution to the pedagogical ideas related to early childhood education that to a large extent conduct early childhood education even in contemporary postmodern and globalized world. However, the theoretical framework of the term and its contents in modern early childhood education does not offer detailed description and would rather be characterized as incomplete and fragmented. The current study is an attempt to partly fill the gap between educational theory and practice basing on early childhood teachers' empirical experience and beliefs on children's freedom of choice and taking advantage of the inductive method in exploration of problems. 
The aim of the study is to identify early childhood teachers' beliefs on children's freedom of choice in child-centred educational practice.

The following research questions were posed: (1) what is teachers' general attitude towards children's freedom of choice, the origin of the underpinning knowledge and beliefs, the personal meaning of the concept; (2) what are the benefits and possible risks of the implementation of children's freedom of choice; (3) what are contributory and hindering factors of the implementation of children's freedom of choice?

To identify teachers' beliefs, focus group discussions were conducted with early childhood teachers implementing early childhood curriculum in municipal early childhood education institutions located in Riga, the capital city of Latvia. Data were analysed using the method of qualitative content analysis.

\section{Theoretical framework}

Childhood is a social construct and as such should be contextualized in specific historical and social changes (Ariès, 1962). Therefore, each era comes with its own attitude towards the child based on the values of the society. In postmodern society the importance of children's freedom of choice is determined by the attitude of the society towards human as a value. Freedom is a prerequisite for the human's life in democratic society, at the same time the idea of freedom that is realized as freedom of choice should be balanced with the responsibility for the consequences of the choice (Mūrnieks, 2010).

Historically child's freedom in early childhood education is one of the cornerstones of Montessori (1912) system of pedagogical beliefs. Montessori emphasizes child's freedom to explore and follow its own natural impulses. The child must experience freedom of movement, freedom of exploration, freedom to interact socially, and freedom from interference from others that leads to a freedom of choice. Montessori's view on child's freedom is very broad and comprehensive. She believes that the concept of liberty (the concept liberty used in English translation of 1912 is considered as a synonym of freedom) in child's earliest years must be understood as demanding those conditions adapted to the most favourable development of his entire individuality (Montessori, 1912). At the same time Montessori recognizes the limited nature of child's freedom. Montessori connects child's freedom with discipline emphasizing that discipline must come through liberty (Montessori, 1912).

The recent research into young children's freedom of choice generally focuses on the psychological aspects arguing that the sense of having a choice promotes motivation and child's free will (e.g., Bao \& Lam, 2008; Chernyak et al., 2010). In some research studies at the end of the 20th century (Iyengar \& Lepper, 1999) freedom of choice has been equated to autonomy. More recent 
studies (Bao \& Lam, 2008) distinguish the terms of autonomy and freedom of choice arguing that it is possible for individuals to feel autonomous when they follow a choice made by others.

Child's freedom of choice is mostly topical in the framework of the childcentred education and is looked at as its essential component (e.g., Perren et al., 2017; Robertson et al., 2015; Tzuo, 2007). At the same time vague boundaries of the concept of child-centred education should be noted. The review of theoretical findings reveals more than 40 meanings of the term ranging from learning based on children's interests to children's participation in decisions related to their learning and to the development of individual potential (Chung \& Walsh, 2000).

The current study is based on the definition of the term as education characterised by the autonomy of children, freedom of choice, responsibility, integration of activities and the acceptance of the role of adults as supporters of learning (Ryan, 2007). Vague theoretical boundaries of child-centredness causes essential differences in its interpretation in educational practice and excludes the possibility to assess dichotomically neither the child-centredness in general nor its individual components, including children's freedom of choice. Thus, children's freedom of choice is understood as a scale of options in different aspects of educational process.

\section{Research methodology}

\section{Research Instrument and Procedure}

To identify empirically early childhood teachers' beliefs on children's freedom of choice in child-centred educational practice the method of focus group was used. Activities were designed for completion in several small groups of teachers. After discussions were carried out in small groups participants shared group opinions in the entire group.

Several sets of questions structured according to the research questions were created for the discussion in the focus group: (1) teachers' general attitude towards children's freedom of choice, the origin of the underpinning knowledge and beliefs and the personal meaning of the concept contents; (2) the benefits and possible risks of the implementation of children's freedom of choice in educational practice; (3) contributory and hindering factors of the implementation of children's freedom of choice.

\section{Participants}

Focus group participants were nine early childhood teachers. All the participants had earned Bachelor's or Master's degree in early childhood pedagogy. Participants ranged in experience working with young children from 10 to 32 years (mean time $=17$ years). Since according to Latvian legislation, 
early childhood education includes children aged from 1 year 6 months to 7 years, selection of focus group participants' focused on inclusion of teachers representing teaching experience of the entire age range of the local early childhood education.

\section{Findings and discussion}

The analysis of early childhood teachers' beliefs reveals versatile view on children's freedom of choice in educational practice and existence of personal understanding of the concept, including benefits and possible risks, as well as contributory and hindering factors of its implementation.

When evaluating own attitude towards children's freedom of choice in educational process teachers mainly express positive attitude using statements like "completely positive", "it goes without saying", "freedom of choice is very important". All the participants agree that their knowledge about child-centred educational practice and children's freedom of choice as its component is acquired in pre-service training contents of higher education or in professional development contents for the teachers with longer working experience. In Latvia, early childhood education focuses on a child-centred approach purposefully since 1990's. State legislation acknowledges the aim of childcentred education content, i.e., to promote child's all-rounded and harmonious development, considering its developmental characteristics and needs, knowledge, skills and attitudes necessary in personal and social life, therefore providing child with an opportunity to prepare purposefully for the acquisition of primary education (Ministru kabinets, 2012). Since 1990's a new generation of teachers has entered early childhood education, thus it could be concluded that the most part of early childhood teachers currently involved in active educational practice has received teaching degree in the conditions of democratic education where respect of child's interests and needs in early childhood education is highly valued.

At the same time, it should be taken into account that the term childcentred education often has been opposed to the term of adult-directed education denoting everything that does not characterize adult-directed educational practice (Robertson et al., 2015) and thus comprising a variety of different educational theories and practices. Vague theoretical boundaries of the concept are the cause of essential differences in the interpretation of childcentred approach in educational practice. Participants agree with the perspective that more freedom of choice children get during the independent play where during the teacher-initiated activities freedom of choice is rather small. Although in educational process play and learning are mostly separated in time as well as in space (Pramling Samuelsson \& Aslund Carlsson, 2008), teachers 
recognize that in practice it is often difficult to separate play and learning, because teacher-initiated activities naturally develop into child-initiated exploration, experimenting or creative activities that have characteristics of both teacher-directed and child-initiated learning. Teachers recognize that blending of play and learning is a productive way of acquiring learning skills for highly selfmotivated children, but a necessary prerequisite is the choice given to the child, i.e., less interested children "finish" the task faster and begin independent play not connected with the theme of learning, while highly interested children continue to explore the theme of learning during independent activities that started as teacher-initiated but developed as completely child-directed.

Teachers recognize the activities in the educational process that could be considered as obligatory, i.e., presence in the morning circle. Individualized approach in implementing children's freedom of choice by taking into account children's age and individual psychological characteristics such as selfregulation skills and self-awareness is essential.

Table 1 Early childhood teachers' beliefs on children's freedom of choice

\begin{tabular}{|c|c|c|}
\hline Belief category & Subcategories & Indicators \\
\hline \multirow{3}{*}{$\begin{array}{l}\text { Teachers' general } \\
\text { attitude towards } \\
\text { children's freedom } \\
\text { of choice and } \\
\text { origins } \\
\text { underpinning } \\
\text { knowledge and } \\
\text { beliefs }\end{array}$} & $\begin{array}{l}\text { General democratic } \\
\text { tendencies of education } \\
\text { in Latvia since 1990's }\end{array}$ & $\begin{array}{l}\text { Attitude of the society towards human as a } \\
\text { value } \\
\text { The child-centred goals of education }\end{array}$ \\
\hline & $\begin{array}{l}\text { Teachers' professional } \\
\text { education }\end{array}$ & $\begin{array}{l}\text { Contents of pre-service training in higher } \\
\text { education } \\
\text { Contents of professional development }\end{array}$ \\
\hline & Educational practice & $\begin{array}{l}\text { Requirements of state legislation } \\
\text { Requirements within the early childhood } \\
\text { education setting }\end{array}$ \\
\hline \multirow{3}{*}{$\begin{array}{l}\text { Teachers' personal } \\
\text { understanding of } \\
\text { children's freedom } \\
\text { of choice }\end{array}$} & $\begin{array}{l}\text { Child-centred } \\
\text { principles of child- } \\
\text { teacher communication }\end{array}$ & $\begin{array}{l}\text { Teacher's ability to accept child's different } \\
\text { view } \\
\text { Encouraging questioning }\end{array}$ \\
\hline & $\begin{array}{l}\text { The limited nature of } \\
\text { children's freedom of } \\
\text { choice }\end{array}$ & $\begin{array}{l}\text { Mandatory activities of educational process, } \\
\text { e.g., presence in the morning circle time } \\
\text { Differences in the degree of children's } \\
\text { freedom of choice during teacher-directed } \\
\text { learning activities and children's } \\
\text { independent play }\end{array}$ \\
\hline & $\begin{array}{ll}\text { The necessity of an } \\
\text { individualized } & \\
\text { approach } & \text { to } \\
\text { implementation } & \text { of } \\
\text { children's freedom of } \\
\text { choice }\end{array}$ & $\begin{array}{l}\text { Dependence of the degree of child's } \\
\text { freedom of choice on child's development } \\
\text { Dependence of the degree of child's } \\
\text { freedom of choice on child's self-regulation } \\
\text { skills } \\
\text { Dependence of the degree of child's } \\
\text { freedom of choice on child's self-awareness }\end{array}$ \\
\hline
\end{tabular}


Conclusion based on the above-mentioned is that teachers' beliefs on children's freedom of choice root in general democratic tendencies of education in Latvia since 1990's, teachers' professional education and requirements for educational practice on state legislative and institutional level. By general very positive attitude towards children's freedom of choice teachers have individualized personal understandings about child-centred principles of childteacher communication, limitations and implementation of an individualized approach (see Table 1).

Teachers recognize some psychological factors as benefits of implementation of child's freedom of choice: (1) development of selfawareness, (2) intrinsic motivation for participation in learning. Some emotional factors are also mentioned among the benefits: (3) children's well-being in early childhood environment, (4) resistant positive emotional condition. Teachers clearly recognize (5) versatile development of children's autonomy as a result of practicing freedom of choice (see Table 2).

Table 2 Benefits and possible risks of the implementation of children's freedom of choice

\begin{tabular}{|c|c|c|}
\hline Belief category & Subcategories & Indicators \\
\hline \multirow[t]{2}{*}{$\begin{array}{l}\text { Benefits from } \\
\text { children's } \\
\text { freedom of } \\
\text { choice }\end{array}$} & $\begin{array}{l}\text { Children's benefits from } \\
\text { children's freedom of } \\
\text { choice }\end{array}$ & $\begin{array}{l}\text { Development of self-awareness } \\
\text { Increasing children's intrinsic motivation } \\
\text { for participation in learning } \\
\text { Child's wellbeing in early childhood } \\
\text { environment } \\
\text { Resistant positive emotional condition } \\
\text { Children's autonomy }\end{array}$ \\
\hline & $\begin{array}{lcr}\begin{array}{l}\text { Teachers' } \\
\text { children's } \\
\text { choice }\end{array} & \begin{array}{r}\text { benefits freedom } \\
\text { from }\end{array} \\
\end{array}$ & $\begin{array}{l}\text { Opportunity for the teacher to get new } \\
\text { information and learn from the children } \\
\text { Opportunity to involve children in } \\
\text { planning }\end{array}$ \\
\hline \multirow[t]{3}{*}{ Possible risks } & $\begin{array}{l}\text { Children's knowledge and } \\
\text { skills }\end{array}$ & $\begin{array}{l}\text { Probability that children do not sufficiently } \\
\text { acquire the necessary knowledge and skills } \\
\text { Vague and unclear structure of a learning } \\
\text { activity } \\
\text { Essential digression from the theme of } \\
\text { learning }\end{array}$ \\
\hline & Behaviour problems & $\begin{array}{l}\text { Teacher is not able to manage children's } \\
\text { freedom } \\
\text { Child-dominated educational process }\end{array}$ \\
\hline & Teachers' competencies & $\begin{array}{l}\text { Need for very broad knowledge and } \\
\text { erudition to be able to address child's } \\
\text { interests comprehensively } \\
\text { Stress management }\end{array}$ \\
\hline
\end{tabular}


Through analysis of the factors that contribute or hinder child's freedom of choice, it can be concluded that high importance is granted to the collaboration with parents and especially similar attitude of teachers and parents towards child's autonomy and freedom of choice. Teachers recognize the impact of family upbringing as both contributing and hindering aspect. Researchers recognize that parents in Latvia mostly trust kindergartens (preschool education institutions - term currently used in legal terminology) as institutional form of early childhood education which both historically and today had allowed families to assign part of educational functions to early childhood settings (Žogla et al., 2011). Teachers recognize increasing disinterest of parents in child's everyday life, assigning responsibility for child's development to an early childhood setting and other similar tendencies that are in a way dark side of post-Soviet state early childhood education based on a long-lasting centralised and well-developed system (Žogla et al., 2011). In the meantime, researchers note growing interest and anxiety in treating children as consumers (Stearns, 2006).

Along with the family impact teachers recognize organisational aspects of educational process and factor of learning environment (see Table 3).

Table 3 Contributory and hindering factors of the implementation of children's freedom of choice

\begin{tabular}{|c|c|c|}
\hline Belief category & Subcategories & Indicators \\
\hline \multirow{4}{*}{$\begin{array}{l}\text { Factors } \\
\text { contributing to } \\
\text { children's } \\
\text { freedom of } \\
\text { choice }\end{array}$} & $\begin{array}{l}\text { Upbringing and attitude } \\
\text { towards child's freedom } \\
\text { of choice in the family }\end{array}$ & $\begin{array}{l}\text { Parent interest in child's everyday life } \\
\text { Parent involvement in children's learning }\end{array}$ \\
\hline & $\begin{array}{l}\text { Organisational aspects } \\
\text { of educational process }\end{array}$ & $\begin{array}{l}\text { Opportunity to involve teacher's assistant in } \\
\text { learning } \\
\text { Opportunity to collaborate with the single } \\
\text { subject teachers like music and sports }\end{array}$ \\
\hline & Learning environment & $\begin{array}{l}\text { Plentiful of tools } \\
\text { Diversity of educational materials }\end{array}$ \\
\hline & $\begin{array}{l}\text { Teacher's professional } \\
\text { development }\end{array}$ & $\begin{array}{l}\text { Opportunity for appropriate teacher's } \\
\text { professional development activities } \\
\text { Opportunity to use professional development } \\
\text { days for preparation of teaching materials }\end{array}$ \\
\hline \multirow{2}{*}{$\begin{array}{l}\text { Factors } \\
\text { hindering } \\
\text { children's } \\
\text { freedom of } \\
\text { choice }\end{array}$} & $\begin{array}{l}\text { Upbringing and attitude } \\
\text { towards child's freedom } \\
\text { of choice in the family }\end{array}$ & $\begin{array}{l}\text { Parent disinterest in child's everyday life } \\
\text { Limited experience of freedom of choice in } \\
\text { the family }\end{array}$ \\
\hline & $\begin{array}{l}\text { Organisational aspects } \\
\text { of educational process }\end{array}$ & $\begin{array}{l}\text { Age gap of children in multi-age early } \\
\text { childhood group too broad } \\
\text { Single subject classes like music, sports, } \\
\text { speech therapist scheduled in the middle of } \\
\text { educational process }\end{array}$ \\
\hline
\end{tabular}




\begin{tabular}{|l|l|l|}
\hline \multirow{2}{*}{ Learning environment } & $\begin{array}{l}\text { Size of classroom and lack of extra space } \\
\text { Insufficient or outdated tools } \\
\text { Insufficient educational materials }\end{array}$ \\
\cline { 2 - 3 } & $\begin{array}{l}\text { Teacher's competencies } \\
\text { and teaching practice }\end{array}$ & $\begin{array}{l}\text { Lack of skill to divide attention evenly for all } \\
\text { children } \\
\text { Overload of teachers working in more than } \\
\text { one educational institution }\end{array}$ \\
\hline
\end{tabular}

\section{Discussion}

Further research needs to be undertaken to examine the correspondence of the ascertained views within a larger sample of early childhood teachers and to identify the extent of verity of the data on the situation in early childhood educational practice. There is a risk that the research data present a rather optimistic perspective. From such perspective, focus group discussions should be considered to be the first stage of the study requiring further research and triangulation of qualitative and quantitative data.

It is important also to take into account the fact that teachers' beliefs might not correspond with the real educational practice (Kimer et al., 2016). Researchers also notice that teachers' self-efficacy could be a stronger predictor of educational practice than teachers' beliefs related to teaching approach (Perren et al., 2017).

The theoretical findings as well as the teachers' beliefs reveal that changing the daily practices of teachers involves more than changing the curriculum and other national documents and providing theoretical training on the new approach to learning. Educational practice clearly demonstrates the necessity of specific guidelines on how to change practice and how to provide feedback for teachers on their work (Kimer et al., 2016).

\section{Conclusions}

Although results of the study cannot be generalized since they do not represent the beliefs of the majority of the teachers, it should be noted that they highlight some very essential tendencies concerning teachers' attitude towards children's freedom of choice within educational practice, therefore highlighting directions for the further research.

First, children's freedom of choice is considered to be a typical trend of modern early childhood educational practice determined by teachers' personal understanding of the essence of children's freedom of choice as well as its relatively high position in the hierarchy of teachers' educational values. The opportunities for the freedom of choice are provided through child-centred 
educational practice as a framework and prerequisite for implementing children's freedom of choice. The teachers' perspectives deeply root in general democratic tendencies characterizing the education of Latvia since 1990's on both - state legislative and institutional - levels.

Child's freedom of choice in early childhood educational practice is implemented to varying degrees ranging from episodic respect towards child's freedom of choice to active encouragement of it with inclusion of extensive and varied domains for implementation of child's freedom of choice. The extent of freedom of choice is determined by children's age and level of self-experience as well as teacher's skills to manage it. Curriculum requirements and teacher's competencies determine the limited nature of children's freedom of choice in educational process.

Secondly, the main benefit provided by freedom of choice is development of self-awareness, intrinsic motivation for participation in learning, children's well-being in early childhood environment, resistant positive emotional condition and child's autonomy.

Thirdly, implementation of child's freedom of choice could be promoted or hindered by the impact of family, organisational aspects of educational process and factor of learning environment.

\section{References}

Ariès, P. (1962). Centuries of childhood: A social history of family life. New York: Vintage Books.

Bao, X., \& Lam, S. (2008). Who makes the choice? Rethinking the role of autonomy and relatedness in Chinese children's motivation. Child development, 79 (2), 269-283. doi: 10.1111/j.1467-8624.2007.01125.x

Chernyak, N., Kushnir, T., \& Wellman, H. (2010). Developing notions of free will: Preschoolers' understanding of how intangible constraints bind their freedom of choice. Proceedings of the Thirty-Second Annual Meeting of the Cognitive Science Society, pp. 2601-2606.

Chung, S., \& Walsh, D. J. (2000). Unpacking child-centredness: A history of meanings. Journal of Curriculum Studies, 32 (2), 215-234. doi: 10.1080/002202700182727

Iyengar, S. S., \& Lepper, M. R. (1999). Rethinking the role of choice: A cultural perspective on intrinsic motivation. Journal of Personality and Social Psychology, 76 (3), 349-366. doi: $10.1037 / 0022-3514.76 .3 .349$

Kimer, M., Tuul, M., \& Õun, T. (2016). Implementation of different teaching practices in early childhood education practice in Estonia. Early Years, 36 (4), 368-382. doi: 10.1080/09575146.2015.1118443

Ministru kabinets (2012). Ministru kabineta noteikumi Nr. 533 „Noteikumi par pirmsskolas izglīīibas vadlīnijām”. Retrieved from http://likumi.lv/doc.php?id=250854.

Montessori, M. (1912). The Montessori method: Scientific pedagogy as applied to child education in "The Children's Houses" with additions and revisions by the author. New York: Frederick A. Stokes Company. 
Mūrnieks, A. (2010). Sabiedrības kultūras ietekme uz izglītības mērḳu veidošanu izglītības vadības kontekstā Latvijā. Promocijas darbs. Rīga: Latvijas Universitāte.

Perren, S., Herrmann, S., Iljuschin, I., Frei, D., Körner, C., \& Sticca, F. (2017). Child-centred educational practice in different early education settings: Associations with professionals' attitudes, self-efficacy and professional background. Early Childhood Research Quaterly, 38, 137-148. doi: 10.1016/j.ecresq.2016.07.001

Pramling Samuelsson, I., \& Asplund Carlsson, M. (2008). The playing learning child: Towards a pedagogy of early childhood. Scandinavian Journal of Educational Research, 52 (6), 623-641. doi: 10.1080/00313830802497265

Robertson, L. H., Kinos, J., Barbour, N., Pukk, M., \& Rosqvist, L. (2015). Child initiated pedagogies in Finland, Estonia and England: Exploring young children's views on decisions. Early Childhood Development and Care, 185 (11-12), 1815-1827. doi: 10.1080/03004430.2015.1028392

Ryan, S. (2007). Pedagogy, child-centered. In: R. S. New \& M. Cochran (Eds.) Early childhood education: An international encyclopedia, vol. 3 (pp. 601-604). London: Praeger.

Stearns, P. N. (2006). Childhood in world history. New York: Routledge.

Tzuo, P. W. (2007). The tension between teacher control and children's freedom in a childcentered classroom: Resolving the practical dilemma through a closer look at the related theories. Early Childhood Education Journal, 35 (1), 33-39. doi: 10.1007/s10643-0070166-7

Žogla, I., Černova, E., \& Kalniņa, D. (2011). Schools of Latvia for learners: System and its management. International Forum for Education, 2011 (1), 44-63. 